\title{
Living Status/Shelter of Street Families of Kolkata: Prospects and Challenges
}

\author{
Harasankar Adhikari \\ Social Worker and Independent Scholar, Kolkata, India \\ Email: jaoya123@yahoo.co.in
}

Received 2 July 2014; revised 4 August 2014; accepted 16 September 2014

Copyright (C) 2014 by author and OALib.

This work is licensed under the Creative Commons Attribution International License (CC BY). http://creativecommons.org/licenses/by/4.0/

(c) (i) Open Access

\begin{abstract}
Kolkata is a densely populated city of eastern India with an estimated population of about 10 million and it is the fourth largest city in India (after Mumbai, Delhi and Bangalore). A huge number of the population has settled their family on the pavements/streets or in the unauthorized slums (jhupri at canal side) of Kolkata for more than 40 years after migration from different districts of West Bengal and its neighboring states like Bihar, Orissa \& Uttar Pradesh and from the neighboring country, Bangladesh and Nepal for securing their better living and it is a continuous process. But, there they live without requisite facilities and it is unprotected without any doubt. This present paper examines living status/shelter of street dwellers of Kolkata and their strategies for its improvement in future. For the purpose of the study, qualitative and quantitative data had been collected through adopting a random purposive sampling. Five hundred members of street families of different parts of Kolkata were interviewed in respect of their age, sex, religion, education, occupation, connecting person and etc. using a structured interview schedule. The information on their better shelter had also been collected through focus group discussion. From the study, it reveals that safe shelter was a prime hindrance for their survival. Due to absence of this, women's privacy and security were violated. For their better shelter the majority of them were indifferent and only $10 \%$ of them had taken initiative on their own for safe shelter at the suburban area of the city.
\end{abstract}

\section{Keywords}

Street Families, Shelter, Economy of Street Families, Women's Privacy and Security

Subject Areas: Politics, Sociology

\section{Introduction}

Shelter/housing is one of the basic human necessities. It is "an extension of human personality" (Pt. Jawaharlal

How to cite this paper: Adhikari, H. (2014) Living Status/Shelter of Street Families of Kolkata: Prospects and Challenges. Open Access Library Journal, 1: e571. http://dx.doi.org/10.4236/oalib.1100571 
Nehru). It is an abode where basic human interaction takes place. The children bring up and acquire the concept of privacy, property, morality and decent citizenship. The social quality of life and living conditions have considerable bearing on health, efficiency and well-being of a human being [1]. So, it is absolutely a productive investment. That's why the housing has been included in our constitution as a state subject. It has become a common duty of the governments to provide the facility of shelter to all specially to the people belonging to the poor and vulnerable section. It has become the integral part of the overall policy of improvement of human settlement and economic development [1].

India faces a huge housing backlog because of the growth of slums, inadequate services, rising cost of shelter and speculation and inadequate supply of formal housing. The UN declaration of "Global Shelter Strategy2001" was pursued by the central and state government in the successive Five Year Plan to frame appropriate policies and programmes. A National Housing Policy (NHP) had been formulated by the Government of India with an object to eradicate homelessness, to improve the housing condition of the inadequately housed and to provide a minimum level of basic services and amenities to all [2]. During the $8^{\text {th }}$ Five Year Plan emphases were given on social housing scheme including those under the minimum needs programme in rural areas, strengthened role of Housing and Development Corporation and National Housing Bank, shelter for the homeless and footpath (pavement) dwellers and others. As per the plan, there are several initiatives in form of scheme taken for fulfilling the basic necessities of shelter of the people of the country [3]. Urban Basic Services was introduced in 1986 with the assistance of UNICEF for provision of basic social services and physical amenities in urban slums. And eventually it was linked with slum clearance/improvement schemes. The scheme provides the assistance to the local bodies for clearance and improvement of slum area and for re-housing of slum families in the lower income bracket. It also included the provision of the construction of night shelters for pavement dwellers in the cities and towns.

Lastly the Kolkata Environment Improvement Project has given exclusive mileage for a better city [4].

But, the situation of a slum and pavement dwellers in terms of their living condition as well as safe space for living is in a tricky. The city uses to face a continuous flow of migration due to changing economic condition and absence of an alternative way of survival of the rural population. To add to it, the surplus labour in agriculture and unemployment are the prime causes of migration to the city [5]. The settlement of migrant people in the area has classified as authorized slums and unauthorized slums. Under the category of unauthorized slums the "jhupri", living at canal side and other vacant places have been included for their survival.

The person living in the "jhupri" or in the street has developed their own household without basic necessities. They are basically the low-paying and unskilled labour in the city (the jobs like rickshaw pulling, rag picking, potteries and so forth). The female of their household is also in workforce and they use to perform the jobs of maidservants, rag picking, etc. The children are also deprived of their basic rights and they use to enter into the earning process rather than their education and other developmental needs [6]. The social, economical and cultural milieu is making their life a critical position [7].

They have had neither almost any conscious about their living nor any initiative for their better shelter in general as a protective measure. They usually depend on the government or others.

The history of migration reminds that they migrated to the city like Calcutta for various reasons. Some migrated just to kill their hunger or to survive; others earned money in order to purchase a piece of land in their village to live in; some parents came for better education of their children, adults or youths in order to learn skills so as to get good work. The percentage of poorest households is very high among families living on the street. Many are daily wage earners, rag pickers, housemaids, mobile sellers of various items such as clothes, aluminum/plastic utensils, low-cost household articles; and some of them are seasonal labour whose earnings are uncertain and not fixed. This class of families has large numbers of family members with low income. The majority of people are unskilled and do not get a good job and thus do not fulfill their economic aspiration. In some cases the parents are bound to send their children to work places as child labour. Because of illiteracy, they are unaware of various schemes of the government. So, street community people often do not access the facilities that might help them.

\section{Review of Literature}

In poverty studies, we find that slums account for most of the poor in the city. Most of the India' urban poor live in overcrowded and unsanitary settlement, commonly known as slum and squatter settlements which are unsafe 
and unsecured shelter without basic infrastructure and services. They are forced to live in illegal and informal settlement because they cannot afford shelter in the housing markets. It realizes that slum dwellers are always poor and they are deprived of housing, education, health and environment [8]. UNCHS [9] introduced the concept of "housing poverty" which includes individuals and households who lack safe, secure and healthy shelter, with basic infrastructure such as piped water and adequate provision for sanitation, drainage and the removal of household waste. The term "slum", thus has wider connotations implying a wide range of low-income settlements with poor living conditions [10]. Urban populations have both higher needs and demands for services and infrastructure. Urban population growth has been fuelled by the prospects of higher incomes and also contributes to the growth process at large. It is unfortunate to notice that the cities failed to deliver the promise of a better quality of life to the expectations [11]. The quality of basic services remained poor, resulting deterioration in the physical environment and quality of life by the widening gap between demand and supply of essential services and infrastructure [12]. The urban poor lack adequate access to services like water supply, sewerage, low-cost housing, education and public health. Thus the urban poor in general and the population living in the slum settlements, in particular have been affected most adversely by urban service deficiencies [13]. Studies also address the problems of urban poor, which helps to narrow the gap between the demand and supply of urban services in low-income communities [2] [8] [9].

So, the objective of the study was to find out problems of street dwellers of Kolkata relating to their shelter/space and secondly, what was their strategic approach towards their better shelter.

\section{Methodology}

For the purpose of the study, qualitative and quantitative data were collected from the pavement/slum dwellers of Kolkata, only metro city of eastern India. Five hundred pavement/slum dwellers was selected randomly in respect of their age, sex, religion, education, occupation, duration of living in the street, etc through purposive simple sampling method. The data were collected through structured interview schedule to know their personal, social and economic background, health, environment, income and other aspects of their daily life in the streets.. The interview lasted for 20 - 30 minutes. Focused Group Discussion (FGD) was applied for qualitative data. 10 FGD consisting 20 members of different age and sex in each group were participated. Researcher recorded extracts of the FGD. The session of the FGD was for 60 - 90 minutes in the local dialect.

\section{Result and Discussion}

\subsection{Description of Street Families of Kolkata}

At Kolkata the migration is a continuous process and the population density is in upwards [5]. A large number of migrant population lives as a slum or pavement dwellers. These people are of rural background with or without any education and as unskilled labour engulfed into the city. They have even no or little knowledge about the city. After getting entry they immediately take their shelter in any places even at the street so that their families consider as street families. The study described the overall situation of the street families at the city.

From the Table 1, it has been observed that the respondent within the age group of 35 - 45 years had dominated as highest (33\%) including 1\% female. Among them, 7\% male was staying for 5 - 10 years on the street and $3 \%$ of them for above 10 years who had come with their relative/known person. Among them, $1 \%$ was female. Then $15 \%$ of the same age group came to Kolkata with their relative, out of which $8 \%$ for less than 5 years, $4 \%$ for 5 - 10 years and 3\% for above 10 years was in the city. On the other hand $7 \%$ came alone in the city with their little knowledge about the city and among them $3 \%$ was staying for above 10 years. Secondly $28 \%$ of them were within the age group of 25 - 35 years and out of which $10 \%$ was female. Among them, $6 \%$ males living in the city since 5 - 10 years came to Kolkata with their relative and $4 \%$ female was under the same category. Only $1 \%$ of the male were for less than 5 years. It has been noted that $13 \%$, out of which $1 \%$ female came to the city alone with their relative/known person. Among them, $6 \%$ was residing since less than 5 years and 7\% was for 5 - 10 years. But remarkably it has been seen that $5 \%$ female of 25 - 35 years came to the city alone and they were residing since 5 - 10 years. Thirdly $30 \%$ including $1 \%$ female of the respondents was within the age group of 45 years and above. Among them, $6 \%$ including $1 \%$ female was arrived with their relative/known person and they were for above 10 years. $16 \%$ of them came with their relative alone and among them $12 \%$ was residing for 10 - 15 years and $4 \%$ was above 10 years. On the other hand $8 \%$ of them came alone and staying for 5 
Table 1. The street families and their history of settlement at Kolkata.

\begin{tabular}{|c|c|c|c|c|c|c|c|c|c|c|c|}
\hline \multirow{4}{*}{$\begin{array}{l}\text { Age group } \\
\text { \& sex }\end{array}$} & & \multicolumn{9}{|c|}{ Person with whom came to Kolkata } & \multirow{4}{*}{ Total } \\
\hline & & \multicolumn{3}{|c|}{$\begin{array}{l}\text { Relative/ known person } \\
\text { with family members }\end{array}$} & \multicolumn{3}{|c|}{ Relative/known person single } & \multicolumn{3}{|c|}{ Alone single } & \\
\hline & & \multicolumn{9}{|c|}{ Duration of staying at Kolkata } & \\
\hline & & $<5$ yrs & 5 - 10 yrs & $\begin{array}{l}\text { Above } \\
10 \text { yrs }\end{array}$ & $<5$ yrs & 5 - 10 yrs & Above 10 yrs & $<5$ yrs & 5 - 10 yrs & $\begin{array}{l}\text { Above } \\
10 \text { yrs }\end{array}$ & \\
\hline \multirow{2}{*}{15 - 25 yrs } & $\mathbf{M}$ & $20(4 \%)$ & - & - & $10(2 \%)$ & - & - & $5(1 \%)$ & - & - & $35(7 \%)$ \\
\hline & $\mathbf{F}$ & $10(2 \%)$ & - & - & - & - & - & - & - & - & $10(2 \%)$ \\
\hline \multirow{2}{*}{25 - 35 yrs } & $\mathbf{M}$ & $5(1 \%)$ & $25(5 \%)$ & - & $25(5 \%)$ & $35(7 \%)$ & - & - & - & - & $90(18 \%)$ \\
\hline & $\mathbf{F}$ & - & $20(4 \%)$ & - & $5(1 \%)$ & - & - & - & $25(5 \%)$ & - & $50(10 \%)$ \\
\hline \multirow{2}{*}{35 - 45 yrs } & $\mathbf{M}$ & - & $35(7 \%)$ & $15(3 \%)$ & $40(8 \%)$ & $20(4 \%)$ & $15(3 \%)$ & - & $20(4 \%)$ & $15(3 \%)$ & $160(32 \%)$ \\
\hline & $\mathbf{F}$ & - & $5(1 \%)$ & - & - & - & - & - & - & - & $5(1 \%)$ \\
\hline \multirow{2}{*}{45 \& above } & $\mathbf{M}$ & - & - & $25(5 \%)$ & - & $60(12 \%)$ & $20(4 \%)$ & - & $20(4 \%)$ & $20(4 \%)$ & $145(29 \%)$ \\
\hline & $\mathbf{F}$ & - & - & $5(1 \%)$ & - & - & - & - & - & - & $5(1 \%$ \\
\hline Total & & $35(7 \%)$ & 85(17\%) & $45(9 \%)$ & $80(16 \%)$ & $115(23 \%)$ & $35(7 \%)$ & $5(1 \%)$ & $65(13 \%)$ & $35(7 \%)$ & $500(100 \%)$ \\
\hline
\end{tabular}

- 10 years and above 10 years in equal number (4\%). Only 9\% of them came within the age group of 15 - 25 years, out of which $2 \%$ was female. All of them were at Kolkata for less than 5 years. And among them $6 \%$ including $2 \%$ female came with their relative with their families. $2 \%$ male came with their relative alone and $1 \%$ came alone.

\subsection{Description of Space of Living and Relationship with Space Providers}

After coming into the city with their relative along with families or alone, they had shared the shelter with their relatives in the pavement/slum locale. But in case of the person who came alone, had passed their night on the Railway platform or its adjacent area. Gradually they came contact with the local power leader in their living place and they arranged their shelter separately in exchange of money or otherwise. Their shelter was fully transitory, small and congested where they could pass their night or leisure period in anyhow. They had to cook outside and there was no toilet or bathing place separately. They had to use the public toilet. Interestingly the chance of getting shelter was not free in any case. They had to share an amount of money to the power leader or their relative once. But majority of them had to bear an amount in cash or kind monthly basis for their continued living in the street. If any family was unable to bear the same they had to supplement it other wise through providing services to the person. Some incidents were also horrible because a portion of them had to share their girls as entertainment to the space provider.

\subsection{The Problem Facing with Their Space of Living}

The shelter of the street families is strictly provisional and it is small and it has been developed in the overcrowding places at pavements or at unauthorized slum. The space for living is in miserable condition where the violation of human rights is distinctly recordable. It is beyond the expectation and even the constitutional provisions are neglected. Although the Govts. (both state and central) are well acquainted with the situation, but they only encase their captive vote. There were no privacy and safety in the living place. The women's condition was in the worst situation without any privacy and safety in their personal life. They had to share the commonplace and they had to manage their menstrual period without any protection and security. The pregnant and lactating mothers were also facing problem of insecurity. The present living condition was a violation of conjugal sexual life. As a consequence of the children of the families was getting orientation with the sexual act from their early childhood. The illicit work as they stated was mostly enjoyable to them and they were experiencing it with their playmates. The study noted the following problems/obstacle faced by the street families in their daily life. 
- The space of living in pavement or in the unauthorized slum locale was fully temporary and eviction was the main threat to them to lose their shelter;

- The space was small, insufficient and congested;

- There was no separate provision of kitchen, bathrooms or toilets;

- The sanitation and drainage were in the worst condition.

\subsection{Economic Condition of the Street Families}

The member of the street families of different ages were in different low paying, unskilled and semi skilled work available in the city as a means of their daily bread (Table 2). The women and children were also engaged in different works for earning. The system of their living was like as earn to live.

From the Table 2, it has been also seen that the members of the street families were engaged in different job for their daily living. Highest percentage (23\%) of them of male was engaged as porter of different age groups. While $5 \%$ of them were involved in rag picking and out which 3\% of $15-25$ years of age including $1 \%$ female. The females of 25 - 35 years (2\%) were also in rag picking. Only $2 \%$ males of 25 - 35 years were doing the job of rickshaw pulling. Of the females $8 \%$ of different age were securing their earnings from the job of maidservants where the 25 - 35 years age was the dominating group (5\%). Of them, $8 \%$ were operating the tea stalls in pavements and $14 \%$ of them was daily labourer, out of which $2 \%$ of $25-35$ years was females. But $22 \%$ of them were engaged in otherwise job which not had been disclosed and among them $4 \%$ were females.

The street families were maintaining their daily survival with basic needs from their earning. But they were mostly incurring their earning for their entertainment purpose matching with the city life. They had the modern entertainment machineries like television, and video cassette players, etc. in their household. They were almost beyond the practice of saving.

\subsection{Women and Girls in the Street Families}

The women and girls of the families had extended their helping hands to restore their survival. They had taken their responsibilities to jointly manage their household set up. Beyond their household chores they were also in earning process. But the basic needs and rights of the females in the families were not looked properly. The relationship in the family was truncated in general. The system of endogamous marriage at an early age was widespread. The pre-marital sex and pregnancies among the teen girls was significant in their life cycle. The marital conflict and marital discord were very much common to them. The extra marital relation was one of the causes of their conflict. Secondly they had a competitiveness and conflict in their occupation/jobs. The women education was not so much the matter of concerned to their families. The girls were attending only the education centres run by the Non-Government Organization (NGOs) in the area. It was their general scope of basic literary

Table 2. Occupational pattern in respect of their age and gender.

\begin{tabular}{|c|c|c|c|c|c|c|c|c|c|}
\hline \multirow{3}{*}{ Nature of occupation } & \multicolumn{8}{|c|}{ Age groups } & \multirow{3}{*}{ Total } \\
\hline & \multicolumn{2}{|c|}{15 - 25 years } & \multicolumn{2}{|c|}{25 - 35 years } & \multicolumn{2}{|c|}{35 - 45 years } & \multicolumn{2}{|c|}{45 years and above } & \\
\hline & M & $\mathrm{F}$ & M & F & M & $\mathrm{F}$ & M & $\mathrm{F}$ & \\
\hline Rag picking & $10(2 \%)$ & $5(1 \%)$ & - & $10(2 \%)$ & - & - & - & - & $25(5 \%)$ \\
\hline Porter & $10(2 \%)$ & - & $30(6 \%)$ & - & $30(6 \%)$ & - & $45(9 \%)$ & - & $115(23 \%)$ \\
\hline Rickshaw puller & - & - & $10(2 \%)$ & - & - & - & - & - & $10(2 \%)$ \\
\hline Hackawing & - & - & $20(4 \%)$ & - & $30(6 \%)$ & - & $40(8 \%)$ & - & $90(18 \%)$ \\
\hline Maid servant & - & $5(1 \%)$ & - & $25(5 \%)$ & - & $5(1 \%)$ & - & $5(1 \%)$ & $40(8 \%)$ \\
\hline Tea stall & $5(1 \%)$ & - & $5(1 \%)$ & - & $10(2 \%)$ & - & $20(4 \%)$ & - & $40(8 \%)$ \\
\hline Daily labour & - & - & $5(1 \%)$ & $5(1 \%)$ & $30(6 \%)$ & - & $30(6 \%)$ & - & $70(14 \%)$ \\
\hline Others & $10(2 \%)$ & - & $20(4 \%)$ & $10(2 \%)$ & $60(12 \%)$ & - & $10(2 \%)$ & - & $110(22 \%)$ \\
\hline Total & $35(7 \%)$ & $10(2 \%)$ & $90(18 \%)$ & $50(10 \%)$ & $160(32 \%)$ & $5(1 \%)$ & $145(29 \%)$ & $5(1 \%)$ & $500(100 \%)$ \\
\hline
\end{tabular}


and numerical skill development. But it was for a certain period depending upon the follow up of the service organization (NGOs). These NGOs were in the process to generate awareness for their schooling and it was also admitting them into formal school for further education. But the monitoring and support of the families were the reason for their dropped out at an early stage. As a result of this they had to look after their household chores and gradually they had to enter into the work force for earning. The women folks in street families were seriously in far away for their equity and justice. The joint family management and decision making in the families had acquired little place. So, the male domination and negligence had put them in darkness in spite of living in the Metro city like Kolkata. Their womanhood was in traditional norms of doing household chores, sexual fulfillment and procreation of children and so forth. The extra marital relations were frequent in their families. A significant number of women and children were left by their counterpart. The health condition of the women and children in the families were not getting proper attention. As consequence of this the women were suffering from reproductive tract infection and other sexual diseases.

\subsection{Plan for Their Better Shelter}

The members of the street families were about 36\% conscious about their better shelter and they were in search of their alternative shelter in the suburban area of extended Kolkata. And if they get chance from any corner they might settle their problem of shelter. On the other part majority $54 \%$ of them were apathetic about their better shelter. But they were in firm believed that the Govt.'s would help to manage their improvement shelter. Only $10 \%$ of them had already purchased the land for their housing in the suburban area of the city and they were very much enthusiastic to shift themselves. For this they were already making the necessary savings to meet their desired needs.

But it has been seen that for their better shelter their consciousness and competitiveness were not so permissive. The level of initiative with neighbours to fulfill their common need collaborate was absent in their mind. They were making a self centric plan for their safe shelter. Interestingly, when their kins or their relatives were in the same place, they were taking separate initiative for their shelter.

\section{Conclusions}

The Kolkata is the gate of eastern India for commerce and business. The city has absorbed the people of different corners for their survival with their basic needs. Rapid industrialization and urbanization have been added to make it a central point of attraction to the people. The migration of population of different parts of the country is in a continuous process. But it is not only absorbed the so-called higher educated and professional, the unemployed and surplus labour in agriculture in rural is also getting opportunity to live in the city with a common purpose of earning. But the safe and secured shelter is the most challenging issue with the population of the city. Urban housing development has given the place of living with the people who are skilled and professional and economically well equipped. But for the population who are poor, unskilled, little or no education, the shelter is a prime hindrance for living in the city. They have mainly chosen the pavement and unauthorized slums for their living where they have to face various obligations. Again a large number of them has been chosen the railway platform and it's surroundings for their space of living. However, after coming into the city they have set up their household with other members of their families. The street families are seriously in difficult condition so far as their space for living is concerned. The shelter is temporary, small and congested one. There is no bathroom and toilet, etc. The condition of the women and girls in their family is worst one. The privacy and safety are violated in their family. The incidents of the sexual abuse or molestation are common at their early age.

The people of street families were engaged mostly in unskilled and low paying job and all the members of the families were almost in earning process. Among them, $23 \%$ were as porter, $5 \%$ of them were as rag picker and $18 \%$ of them were doing the job of hawkers. The females were doing the job of maidservants and rag picking and it was $8 \%$ and $3 \%$ respectively. Some of them were also operating tea stalls in the street. But they were mostly using their earning for their daily bread and personal cause.

Most of them were neglecting the issue of their safe shelter and only $10 \%$ of them were conscious about their better shelter. The above situation had made a worse condition when the women dignity and respect was in violation. In their families the marital conflict and discord were high in nature.

So far as their shelter was concerned the majority of them were expecting help from the Govt. Their own initiative for their better shelter was not so much because of their low earning. The assistance from another source 
can help to restore their space of living where all the benefit and facilities would be there and the women and girls privacy and safety would be ensured.

\section{Recommendations}

The safe and secure shelter is a present day global issue throughout the world. In both rural and urban society large population of the world is under the open sky. It is one of the main aspects of human rights. But the right to shelter is not getting so much priority to the policy makers matching with the requirement. There are so many organizations raising their voice for better shelter for the people of all corners. In India a large number of populations are shelterless. The government level various policy and program like Indra Awas Joyna, etc. have been taken under implementation. But it is not fulfilling the required needs. Further the selection process and other criteria have become burden to choose the needy rightly. Simultaneously rapid urbanization and migration of rural people into the city have been creating problems of shelter in the city or town. Therefore, they are choosing the street/pavements or unauthorized slums for their shelter. The scenario of Kolkata is more complex. The migrated people of lower income group or unskilled population have developed their shelter in the street. The shelter in all aspects is unhygienic, congested and temporary one. From the study it has been seen that the street families were adopted, the situation as it was their fate and fortune. They were not so much conscious about their shelter. The women privacy and security were unprotected. Only a limited number of populations had taken the initiative. So, the following suggestion and recommendation might be followed for better shelter of the street families.

- The consciousness for better shelter would be generated among the members of the street families through education on savings individually or jointly for their better shelter.

- The housing needs would be attentively placed by which their interest on the same would be respected.

- The alternative earning facilities would be introduced among women specially.

- The initiative for a joint venture among the members of the street families would be encouraged as an approach of good neighbourhood.

\section{References}

[1] Sarma, A.N. (1995) Aspects of Labour Welfare and Social Security. Himalaya Publishing House, Mumbay.

[2] Bhattacharya, K.P. and Bhattacharya, S. (1998) Strategies for Adequate, Affordable and Safe Housing in Developing Countries. In: Bhattacharya, K.P., Ed., Affordable Housing and Infrastructure in India, Reliance Publishing House, New Delhi.

[3] India (1993) Ministry of Information and Boardcasting. Government of India, New Delhi.

[4] CMDA (No Date) Kolkata Slum Improvement Project 1991-92. CMDA, Kolkata.

[5] Bardhan and Maitreyi, R. (1994) Kolkata Slums, Public Policy in Retrospect. Minerva Associates, Kolkata.

[6] Bannerjee, P. (1975) Kolkata and Its Hinterland. Progressive Publishers, Kolkata.

[7] Bhattacharya, M. (2001) Urban Environment Management: A Local Governance Perspective. Institute of Social Sciences, New Delhi.

[8] Swaminathan, M. (1995) Aspects of Urban Poverty in Bombay. Environment and Urbanization, 7, 77-91. http://dx.doi.org/10.1177/095624789500700117

[9] Un-Habitat (2003) The Challenge of Slums: Global Report on Human Settlements 2003. Earthscan Publications, London.

[10] Aldrich, B.C. and Sandhu, R.S. (1995) Housing for the Urban Poor. Sage Publications, New Delhi.

[11] Hanumantha Rao, C.H. (1998) Agricultural Growth, Sustainability and Poverty Alleviation. Economic Political Weekly, 33, 613-617.

[12] Bhattacharya, A. (2000) Strategies for Urban Development. The West Bengal Experience Urban Management, 8, 2333.

[13] Chakraborty, A. and Animesh, H. (No Date) Slum Dwellers of Kolkata, Socio-Economic Profile 1989-90. Kolkata. 